\title{
Is low dose inhaled corticosteroid therapy as effective for inflammation and remodeling in asthma? A randomized, parallel group study
}

Melissa Baraket ${ }^{1,2,3,4^{*}}$, Brian GG Oliver ${ }^{1,2}$, Janette K Burgess ${ }^{1,2}$, Sam Lim ${ }^{5}$, Gregory G King ${ }^{1,2,6,7}$ and Judith L Black ${ }^{1,2}$

\begin{abstract}
Background: While most of the clinical benefits of inhaled corticosteroid (ICS) therapy may occur at low doses, results of dose-ranging studies are inconsistent. Although symptom/lung function response to low and high dose ICS medication is comparable, it is uncertain whether low dose ICSs are as effective as high dose in the treatment of inflammation and remodeling.

Methods: 22 mild or moderate asthmatic adult subjects (corticosteroid free for $>2$ months) participated in a randomized, parallel group study to compare effects of fluticasone propionate (FP) $200 \mathrm{mcg} /$ day and $1000 \mathrm{mcg} /$ day. Alveolar macrophage (AM)-derived cytokines and basement membrane thickness (BMT) were measured at baseline and after 7 weeks treatment while symptoms, spirometry, exhaled nitric oxide (eNO) and airway hyperresponsiveness (AHR) to mannitol at baseline and 6 weeks.

Results: FP improved spirometry, eNO, symptoms and AHR with no difference between low and high dose FP. Both high and low dose FP reduced GM-CSF, TNF-alpha and IL-1ra, with no change in BMT and with no differences between low and high dose FP.

Conclusions: $200 \mu \mathrm{g} /$ day of FP was as effective as $1000 \mu \mathrm{g} /$ day in improving asthma control, airway inflammation, lung function and AHR in adults in the short term. Future studies should examine potential differential effects between low and high dose combination therapy (ICS/long acting beta agonist) on inflammation and airway remodeling over longer treatment periods.
\end{abstract}

Keywords: asthma, corticosteroids, airway hyperresponsiveness, alveolar macrophage, airway inflammation, airway remodeling

\section{Background}

Corticosteroids are the most effective medication for the prevention and treatment of asthmatic inflammation. Many dose-ranging studies have been conducted to examine the dose-response relationship of ICSs in the treatment of asthma in adults and children [1-17]. The adverse effects of inhaled corticosteroids (ICSs) have been clearly shown to be dose-related in both adults and children in numerous studies [18-25]. Although it has been suggested that most of the clinical benefits of ICSs occur at low doses $[6,26]$, the results of dose-ranging studies are inconsistent. Some data show no dose-response

\footnotetext{
* Correspondence: melissa.baraket@sswahs.nsw.gov.au

${ }^{1}$ Woolcock Institute of Medical Research, Sydney, NSW, Australia

Full list of author information is available at the end of the article
}

for FEV1 or asthma symptoms [8-11,13,27-29], for airway hyperresponsiveness $[7,14,15]$ or exhaled nitric oxide [15], while other data show a significant dose-response for clinical outcomes [2-5,7,9,12,16,17,30,31].

Evidence for equivalent effects on underlying airway inflammation and remodeling of low dose and high dose ICS therapy is lacking. In vitro, the degree of suppression of some inflammatory cytokines and the degree of upregulation of anti-inflammatory cytokines is dependent on the dose of corticosteroid [32,33]. However, there are no in vivo randomized studies comparing the effects of low and high dose ICS on production of clinically relevant cytokines.

Alveolar macrophages (AMs) normally represent the majority of cells isolated by bronchoalveolar lavage

\section{Biomed Central}

() 2012 Baraket et al; licensee BioMed Central Ltd. This is an Open Access article distributed under the terms of the Creative Commons Attribution License (http://creativecommons.org/licenses/by/2.0), which permits unrestricted use, distribution, and reproduction in any medium, provided the original work is properly cited. 
(BAL) and express allergen-specific low affinity immunoglobulin E (IgE) receptors on their surface [34] which, when activated, release pro-inflammatory mediators and anti-inflammatory regulators including chemokines (IL8, MCP-1, MIP-1 $\alpha$ ), anti-inflammatory cytokines (IL-1ra and IL-10) and pro-inflammatory cytokines (TNF- $\alpha$, GM-CSF, IL-6 and IL-1 $\beta$ ) [35]. Endobronchial allergen challenge significantly increases expression of activation markers on AMs and correlates with AHR to methacholine [36]. The pro-inflammatory cytokine granulocyte macrophage-colony stimulating factor (GM-CSF), secreted by AMs, promotes myeloid cell differentiation, stimulates antigen presenting cells, prolongs eosinophil survival [37] and is elevated in BAL and bronchial biopsies in asthma and after allergen challenge [38-41]. Neutralisation by GM-CSF antibodies in mice abolishes ovalbumin-induced AHR and mucus cell hyperplasia [42]. In vitro incubation of peripheral blood mononuclear cell cultures with beclomethasone dipropionate (BDP) or fluticasone propionate (FP) dose-dependently inhibits allergen-induced GM-CSF in atopic asthmatics [32]. Tumour necrosis factor-alpha (TNF- $\alpha$ ) is another pro-inflammatory mediator secreted by AMs which is increased in symptomatic asthmatics and enhanced by allergen challenge. In vitro incubation with TNF- $\alpha$ increases human airway smooth muscle responsiveness [43]. Inhaled recombinant TNF- $\alpha$ increases AHR to methacholine [44]. In vitro incubation of alveolar macrophages with fluticasone or budesonide results in dose-dependent inhibition of lipopolysaccharide (LPS)induced TNF- $\alpha$ protein secretion [33].

AMs secrete the anti-inflammatory cytokine interleukin10 (IL-10) which inhibits production of many pro-inflammatory cytokines [45], suppresses allergic inflammation by inhibiting T helper 2 cell cytokines [46], shortens eosinophil survival and attenuates induction of IgE synthesis by IL-4 [47]. Studies of the effects of corticosteroid treatment on IL-10 are mixed. IL-10 expression is greater during budesonide treatment compared with placebo [48] and serum IL-10 increases after triamcinolone [49] while inhibition of IL-10 by corticosteroid treatment can also occur [50].

Another anti-inflammatory cytokine secreted by AMs is interleukin-1 receptor antagonist (IL-1ra) which is an endogenous means of protection against inflammatory responses in diseases such as asthma and rheumatoid arthritis by inhibiting the pro-inflammatory mediator interleukin-1beta (IL-1 $\beta$ ). More macrophages express IL$1 \beta$ in asthma [51] and IL-1ra serum levels increase during asthma exacerbations [52]. In animal studies, aerosol IL1ra prior to histamine challenge prevents bronchial hyperresponsiveness [53]. Inhaled BDP in asthmatic subjects inhibits epithelial expression of IL-1 $\beta$ without inhibition of
IL-1ra, favouring an anti-inflammatory shift in the ratio of IL-1 $\beta /$ IL-1ra [54].

There is also some evidence for dose related differences in the effects of corticosteroids on bronchial mucosal basement membrane thickness (BMT) $[55,56]$ but whether low dose ICS therapy, while sufficient to control asthma symptoms, is also adequate to improve airway remodeling is unknown.

The null hypothesis of this study is that low dose ICS therapy is as efficacious as high dose therapy, for asthma control, airway inflammation and remodeling in adults. Our aim was to examine differences in response to high and low dose ICS, in asthma control, airway inflammation, AHR and airway remodeling in mild to moderate adult asthmatics who were previously corticosteroid free for over two months.

\section{Methods \\ Subjects}

Adult volunteers were recruited, aged 19-30 years, with intermittent or mild persistent or moderate persistent atopic asthma (according to Global Initiative for Asthma, Global Strategy for Asthma Management and Prevention, NIH Publication, Updated 2005). Inclusion criteria were asthma symptoms in the preceding 12 months and positive mannitol bronchial provocation test. Exclusion criteria were baseline FEV1 less than $60 \%$ predicted, inhaled or systemic corticosteroid treatment in the preceding 2 months, smoking in the preceding 12 months, greater than 5 pack year smoking history and symptoms of upper respiratory tract infection in the past 6 weeks. The study was approved by the Ethics Review Committee of Royal Prince Alfred Hospital in the Sydney South West Area Health Service (protocol number X02-0137).

\section{Study design}

This was a double-blind, randomized, parallel group comparison of short term low dose $(100 \mu \mathrm{g}$ twice daily) versus high dose (500 $\mu \mathrm{g}$ twice daily) inhaled fluticasone propionate (FP) via metered dose aerosol and large volume spacer (GlaxoSmithKline). Bronchoscopy with lavage and biopsies and bronchodilator reversibility assessment were performed before and after 7 weeks treatment. The other clinical measurements were obtained before treatment and one week prior to the second bronchoscopy, that is, after 6 weeks treatment. The canisters were weighed before and after the treatment period to confirm adherence. Patients were provided with salbutamol metered dose aerosol, $100 \mu \mathrm{g}$, used as needed for asthma symptoms. Skin prick testing was done with a panel of 12 common aeroallergens to assess atopic status. A positive wheal was $3 \mathrm{~mm}$ or more in the presence of a negative control. 
Lung function and airway hyperresponsiveness (AHR)

AHR was measured by bronchial provocation with dry powder mannitol [57]. The test was terminated when the fall in FEV1 reached at least 15\% of baseline or after a cumulative mannitol dose of $635 \mathrm{mg}$ [58]. Response dose ratio (RDR) [57] was the final percent fall in FEV1 divided by the corresponding cumulative dose of mannitol $(\% / \mathrm{mg})$. The provocative dose of mannitol causing a $15 \%$ or greater fall in FEV1 (PD15) was calculated by linear interpolation. The mannitol doubling dose difference $(\mathrm{DDD}(\mathrm{RDR}))$ was calculated as $[\log (\mathrm{RDR})$ pre FP $\log (\mathrm{RDR})$ post $\mathrm{FP}] / \log (2)$.

\section{Exhaled nitric oxide (eNO)}

Exhaled air was collected, prior to any lung function tests, in a nitric oxide impermeable polyethylene reservoir bag using a slow vital capacity manoeuvre via a rotameter to ensure an expiratory flow rate of $200 \mathrm{~mL} / \mathrm{s}$. The fraction of eNO (ppb) was measured offline using a chemiluminescence analyzer (42C, Thermo Environmental Instruments, MA, USA).

Bronchoscopy, alveolar macrophage (AM) culture and AM stimulation, RNA extraction and bronchial biopsy

Three endobronchial biopsies before and after 7 weeks of treatment were snap frozen in optimal cutting temperature medium and stored at $-80^{\circ} \mathrm{C}$ for later sectioning. AMs were isolated from bronchoalveolar lavage fluid by adhesion. After rinsing and reapplication of culture medium, AMs were incubated with or without lipopolysaccharide (LPS) for 24 hours, after which supernatants were stored at $-80^{\circ} \mathrm{C}$ for cytokine protein assay and AMs were harvested for RNA extraction.

\section{AM cytokine quantification}

After reverse transcription, quantitative PCR for each cytokine was performed (Assays-on-Demand, Applied Biosystems, Foster City, California) to obtain a threshold cycle $(\mathrm{Ct})$ with normalisation to $18 \mathrm{~S}$. Cytokine protein concentration in AM culture supernatants was quantified by enzyme-linked immunosorbent assay (ELISA) (DuoSet, R\&D Systems, Minneapolis, USA).

\section{Basement membrane thickness (BMT)}

Frozen biopsies were sectioned at $-18^{\circ} \mathrm{C}$ at a thickness of $7 \mu \mathrm{m}$. Cryosections were stored at $-80^{\circ} \mathrm{C}$ for later staining with haematoxylin and eosin which were then photographed under light microscopy at $60 \times$ power. Transverse measurements of the basement membrane, perpendicular to the mucosal surface, were taken at $10-20 \mu \mathrm{m}$ intervals where the basement membrane appeared intact, clearly delineated and uniform. The mean BMT was calculated from seven to ten measurements on each of two to four sections cut from each of two to three biopsies.

\section{Statistical analysis}

Statistical analyses were conducted using SPSS. Nonparametric variables (eNO, serum IgE, PD15, and RDR) were $\log$ transformed to normal distributions. Comparisons of means for normally distributed data (FEV1, BMT) were calculated by paired samples t-test for paired data and independent samples t-test for unpaired data. For Juniper Asthma Control Questionnaire scores [59], change in threshold cycle $(\Delta \mathrm{Ct})$ and ELISA values which were nonnormally distributed, medians were compared using the Wilcoxon test for paired samples and the Mann-Whitney $\mathrm{U}$ test for unrelated samples. Given the lack of available data quantifying the dose-dependent effects of inhaled corticosteroids on airway cytokines, the sample size was extrapolated from a study of the effects of inhaled budesonide on alveolar macrophage GM-CSF, TNF-alpha and IL-10 protein levels $(\mathrm{pg} / \mathrm{mL})$ [48] and a study of inhaled flunisolide on TNF- $\alpha$ protein [60]. A sample size of 11 subjects in each group was calculated to achieve a power of $80 \%$ and alpha of 0.05 to detect a difference of $1500 \mathrm{pg} /$ $\mathrm{mL}$ in GM-CSF and $260 \mathrm{pg} / \mathrm{mL}$ in IL-10 based on a standard deviation of $1250 \mathrm{pg} / \mathrm{mL}$ for GM-CSF and $220 \mathrm{pg} /$ $\mathrm{mL}$ for IL-10.

\section{Results}

Twenty three subjects completed the protocol in full. Paired clinical and in vitro data were available for 22 participants, of whom 11 had been randomized to low dose and 11 to high dose FP.

\section{Baseline (pre FP) characteristics}

Clinical baseline characteristics of the two treatment groups were not statistically different (table 1 ). Fifteen had reported symptoms and had used a rescue short-acting b2-agonist in the preceding 4 weeks, 21 in the preceding 6 months and all in the preceding 2 years. Sixteen subjects had taken ICSs previously ( 7 in low dose and 9 in high dose FP group) at or longer than 2.5 months prior to study entry, with a median interval since last corticosteroid use of 9 months. Twenty-two had never smoked, while 1 had a 0.2 pack year history and ceased 2 years prior. All subjects were atopic on allergen skin testing and had significant AHR to mannitol.

\section{Comparison of the change in each endpoint between low and high dose FP}

There were no significant differences in mean or median changes in any clinical parameters between low and high dose FP groups (table 2). No statistically significant differences were found in median changes in AM cytokine mRNA expression or protein production between low and high dose FP groups. The difference in mean changes in BMT between low and high dose FP was also not statistically significant. 
Table 1 Clinical baseline characteristics of the asthmatic subjects grouped into low and high dose FP treatment arms

\begin{tabular}{llll}
\hline & $\begin{array}{l}\text { Low Dose FP } \\
(\mathbf{n}=\mathbf{1 1})\end{array}$ & $\begin{array}{l}\text { High Dose FP } \\
\text { (n= 11) }\end{array}$ & p value \\
\hline Age (yrs) & Mean (SD) & Mean (SD) & 0.72 \\
Height (m) & $21.7(2.9)$ & $22.3(4.0)$ & 0.24 \\
Weight (kg) & $1.7(0.1)$ & $1.8(0.1)$ & 0.16 \\
Age of asthma onset (yrs) & $74.1(15.7)$ & $86.8(24.0)$ & 0.22 \\
Duration of asthma (yrs) & $6.7(2.8)$ & $4.8(4.2)$ & 0.37 \\
FEV1 (L) & $14.5(4.0)$ & $16.5(6.1)$ & 0.63 \\
FEV1 \% predicted & $3.49(0.56)$ & $3.63(0.74)$ & 0.84 \\
FVC (L) & $85.6(12.6)$ & $84.5(12.1)$ & 0.60 \\
FEV1/FVC ratio (\%) & $4.59(0.87)$ & $4.79(0.86)$ & 0.74 \\
Bronchodilator response (\%) & $77.4(12.3)$ & $75.9(7.3)$ & 0.54 \\
\hline & $5.6(6.5)$ & $7.0(4.0)$ & $\mathbf{p ~ v a l u e ~}$ \\
\hline Exhaled nitric oxide (ppb) & Geometric Mean & Geometric Mean & \\
Total serum lgE (kU/L) & $\mathbf{( 9 5 \% ~ G R )}$ & $\mathbf{( 9 5 \% ~ G R )}$ & \\
PD15 (mg) & $22.5(5.7-88.5))$ & $24.6(5.7-106.6)$ & 0.77 \\
RDR (\%/mg) & $246.7(19.4-3142.4)$ & $411.7(34.7-4884.3)$ & 0.36 \\
\hline & $178.0(29.3-1080.2)$ & $96.8(20.1-465.8)$ & 0.11 \\
\hline Juniper ACQS & $0.087(0.015-0.478)$ & $0.145(0.030-0.668)$ & 0.16 \\
\hline
\end{tabular}

$\mathrm{GR}=$ geometric range, $\mathrm{IQR}=$ interquartile range, ${ }^{*} \mathrm{n}=10$

Effects of FP on clinical, physiological and in vitro parameters

Because no significant differences were found between the low and high dose treatment groups, the effect of FP on the 22 asthmatics as a single group was evaluated. As shown in Figure 1, FP resulted in significant improvement in FEV1 \% predicted, eNO and Juniper symptom score in this group of asthmatic subjects. There was also marked attenuation of AHR manifest by a significant fall in RDR after FP. Significant improvements were also

Table 2 Change in each endpoint after FP in low and high dose treatment arms

\begin{tabular}{|c|c|c|c|}
\hline & $\begin{array}{l}\text { Low dose FP } \\
(\mathrm{n}=11)\end{array}$ & $\begin{array}{l}\text { High dose FP } \\
(n=11)\end{array}$ & \\
\hline & Mean (SD) & Mean (SD) & $p$ value \\
\hline change in FEV1 $(L)$ & $0.291(0.512)$ & $0.364(0.356)$ & 0.703 \\
\hline change in percent predicted FEV1 (\%) & $6.5(11.1)$ & $8.0(7.1)$ & 0.719 \\
\hline change in FEV1/FVC ratio after FP (\%) & $3.5(4.6)$ & $5.7(6.1)$ & 0.336 \\
\hline change in Bronchodilator response (\%) & $0.1(7.8)$ & $2.7(5.5)$ & 0.376 \\
\hline change in log RDR $(\% / m g)$ & $0.955(0.530)$ & $0.751(0.433)$ & 0.335 \\
\hline change in log exhaled NO (ppb) & $0.307(0.259)$ & $0.427(0.304)$ & 0.331 \\
\hline Mannitol Doubling Dose Difference & $3.2(1.8)$ & $2.5(1.4)$ & 0.335 \\
\hline \multirow[t]{2}{*}{ change in basement membrane thickness ( $\mu \mathrm{m})$} & $-0.27(1.08)$ & $0.56(1.38)$ & 0.133 \\
\hline & Median (IQR) & Median (IQR) & $p$ value \\
\hline change in Juniper ACQS & $0.5(0-1.0)$ & $1.0(0-1.0)$ & 0.969 \\
\hline change in LPS induced TNF-alpha mRNA (Ct) & $0.1(-0.7-1.7)$ & $0.7(-0.4-2.1)$ & 0.797 \\
\hline change in LPS induced GM-CSF mRNA (Ct) & $1.7(-1.4-3.8)$ & $2.9(-1.9-5.0)$ & 0.748 \\
\hline change in LPS induced IL-1ra mRNA (Ct) & $3.2(2.0-4.3)$ & $3.3(1.3-5.7)$ & 0.606 \\
\hline change in LPS induced IL-10 mRNA (Ct) & $-0.6(-1.2-1.7)$ & $0.5(-0.7-1.2)$ & 0.332 \\
\hline change in LPS induced TNF-alpha protein $(\mathrm{pg} / \mathrm{mL})$ & $830(-3888-1302)$ & $-2860(-9173-2716)$ & 0.395 \\
\hline change in LPS induced GM-CSF protein (pg/mL) & $307(-414-2986)$ & $418(-619-1154)$ & 0.768 \\
\hline change in LPS induced IL-1ra protein (pg/mL) & $4035(1493-58151)$ & $10166(-1631-15164)$ & 0.922 \\
\hline change in LPS induced IL-10 protein (pg/mL) & $0.5(-75.6-19.2)$ & $1.3(-44.5-79.7)$ & 0.622 \\
\hline
\end{tabular}

$\mathrm{SD}=$ standard deviation, $\mathrm{IQR}=$ interquartile range, $\mathrm{Ct}=$ threshold cycle 


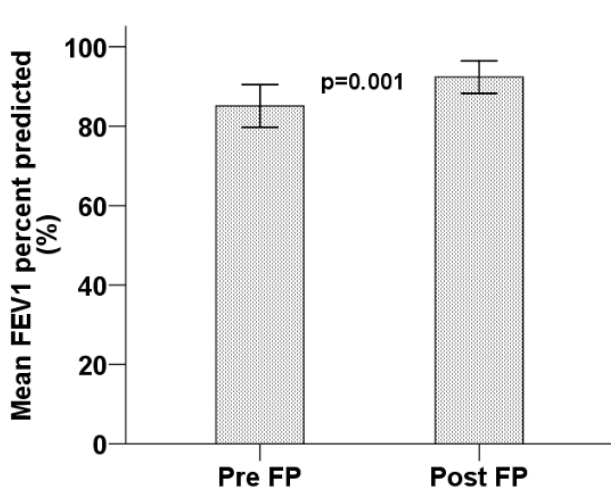

(a)

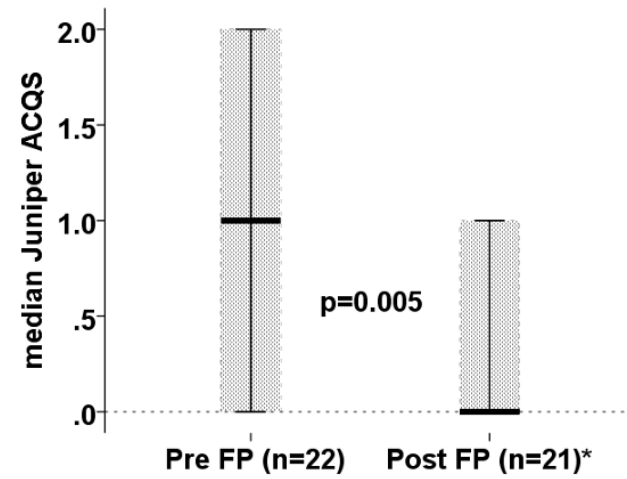

(c)

Figure 1 Effects of FP on clinical parameters $(\mathbf{n}=\mathbf{2 2}$ ). (a) FEV1 \% predicted, (b) Exhaled nitric oxide ( $p$ value derived from log eNO means), (c) Juniper ACQS, (d) log RDR for mannitol. Columns represent means and error bars represent $95 \%$ confidence intervals. Juniper scores are depicted by box and whisker plots with medians and interquartile ranges ( ${ }^{*} n=21$ for post Juniper ACQS). demonstrated in FEV1 [pre FP: 3.56L (SD 0.64), post FP: 3.89L (SD 0.70), $\mathrm{p}=0.002$ ] and FEV1/FVC ratio [pre FP: $77 \%$ (SD 9.9\%), post FP: $81 \%$ (SD 7.4\%), p = 0.001].

LPS significantly enhanced the quantity of cytokine mRNA expressed and protein produced by AMs. FP treatment significantly reduced constitutive mRNA expression of GM-CSF, TNF- $\alpha$ and constitutive or LPS induced IL-1ra mRNA (Figure 2) and protein (Figure 3). There was no significant effect of inhaled FP on GMCSF or TNF- $\alpha$ protein concentrations. There was no significant effect of inhaled FP on IL-10 which was in many samples below the lower limit of detection.

There was no significant change in BMT in the group as a whole $(\mathrm{n}=22), 9.21 \mu \mathrm{m}(\mathrm{SD} 1.02)$ before and $9.06 \mu \mathrm{m}$ (SD 0.91) after FP treatment.

\section{Discussion}

In this study we found that seven weeks of low dose ICS treatment in adults with mild to moderate asthma, who were corticosteroid free for over 2 months, is as effective in controlling airway inflammation as high dose therapy,

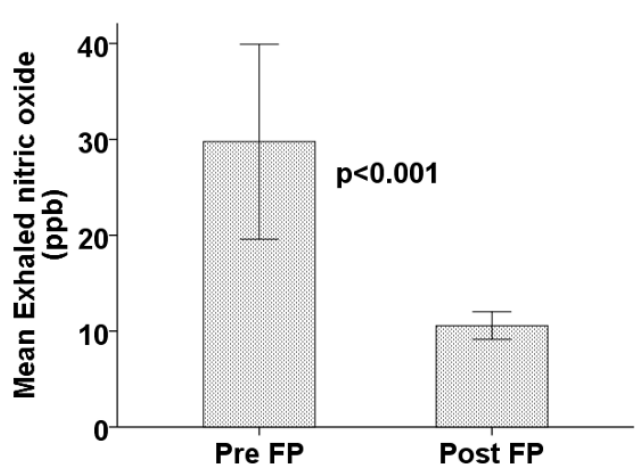

(b)

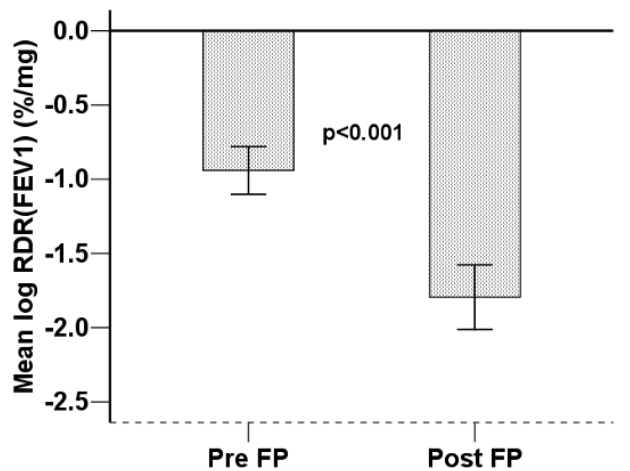

(d)

measured by constitutive mRNA expression of GM-CSF, TNF- $\alpha$ and constitutive or LPS induced IL-1ra mRNA and protein in BAL. Low and high doses were also equally effective in controlling asthma in terms of symptoms, spirometry, eNO and AHR after 6 weeks, which is consistent with previous data $[6,26]$. We found no significant effects on airway remodeling by either dose after 7 weeks, as measured by change in basement membrane thickness.

There have been previous ICS dose-ranging trials which have not found differential clinical effects between dose arms. Meta-analyses have revealed plateaus in the ICS dose-response curve beginning at 100-200 $\mu$ g of FP per day with a peak benefit at $500 \mu \mathrm{g} /$ day [11] or most of the clinical efficacy attained with an FP dose of $200 \mu \mathrm{g} /$ day [6] or 300-600 $\mu \mathrm{g} /$ day of budesonide (BUD) [26]. However, control of underlying inflammation and remodeling was not assessed and individual patients with more severe asthma may require higher doses to achieve the corresponding maximal effects. Previously published evidence suggests that AHR, which is loosely related to inflammation, may be 
(a)

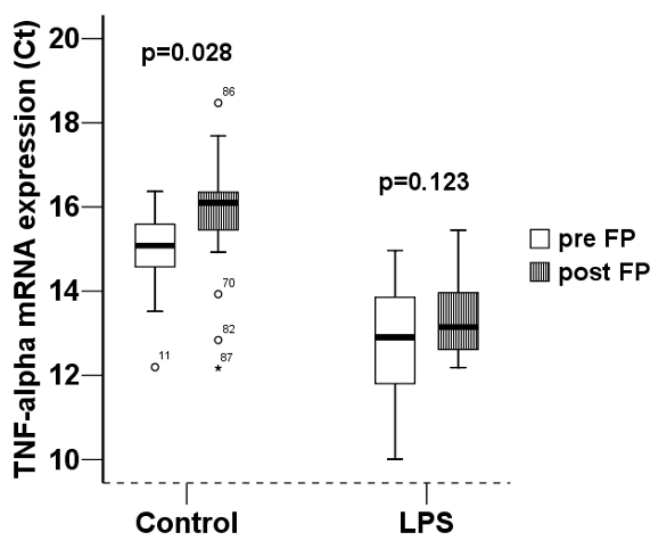

(c)

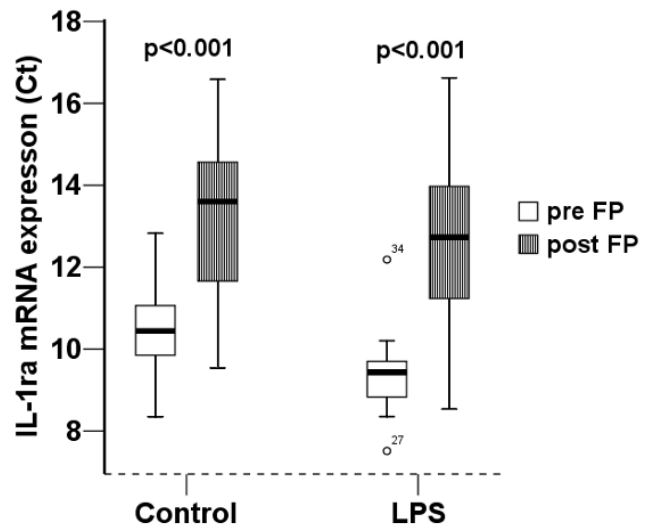

Figure 2 Comparison of cytokine mRNA expression pre and post FP ( $\mathbf{n}=\mathbf{2 2}$ ). (a) TNF- $\alpha$, (b) GM-CSF, (c) IL-1 ra, (d) IL-10. Results are normalized for $18 \mathrm{~S} . \mathrm{Ct}=$ threshold cycle. LPS $=$ Lipopolysaccharide. Control $=$ unstimulated sample. Graphical representation is by box and whisker with medians and interquartile ranges. Note: an increase in threshold cycle indicates a decrease in quantity of mRNA present. more likely to show ICS dose-dependence than FEV1, PEF or symptoms $[9,12,31,61]$ and a dose-dependent rate of reduction of eNO and asthma symptoms has been observed $[7,16,17]$. In a meta-analysis of sixteen trials using multiple drug formulations (FP, triamcinolone, BUD and mometasone), a statistically significant inhaled corticosteroid dose-response relationship was found for morning PEF and a dose-response relation for FEV1 was found for BUD [2]. Asthma symptom score was also differentially affected by the dose of FP or triamcinolone, in contrast to the present study finding of no difference in change in Juniper score between the two doses. This absence of difference in the present study may be due to a milder degree of asthma and smaller sample size.

Despite the small sample size in a study by Chetta et al. [56] (8 in each group), there were significant differences in a number of in vitro inflammatory indices between low and high dose inhaled steroid treatment. High dose treatment resulted in a significant decrease in basement membrane thickness, number of vessels, vascular area and mean vessel size whereas no change was observed with low dose. Like the current study findings, there were no significant differences in the improvements in AHR and asthma symptom scores between the groups. The lack of difference between high and low dose ICS effect on inflammatory markers in the present study, compared with the findings of Chetta et al. [56] could be due to milder asthma in our subjects since none had previously taken long term ICS regularly. This is supported by the correlation observed between baseline severity and magnitude of improvement in outcomes.

Modulation of alveolar macrophage inflammatory responses is an important mechanism underlying ICS efficacy in asthma [34-36,62-65]. There are no published randomized studies examining the dose-response relationship of the effect of ICSs on pro- and anti-inflammatory cytokine production in asthma. In the present 
(a)

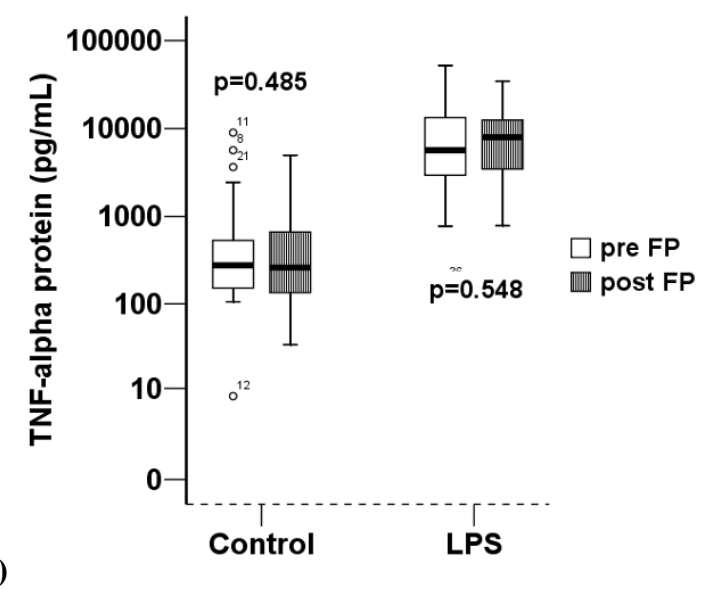

(b)
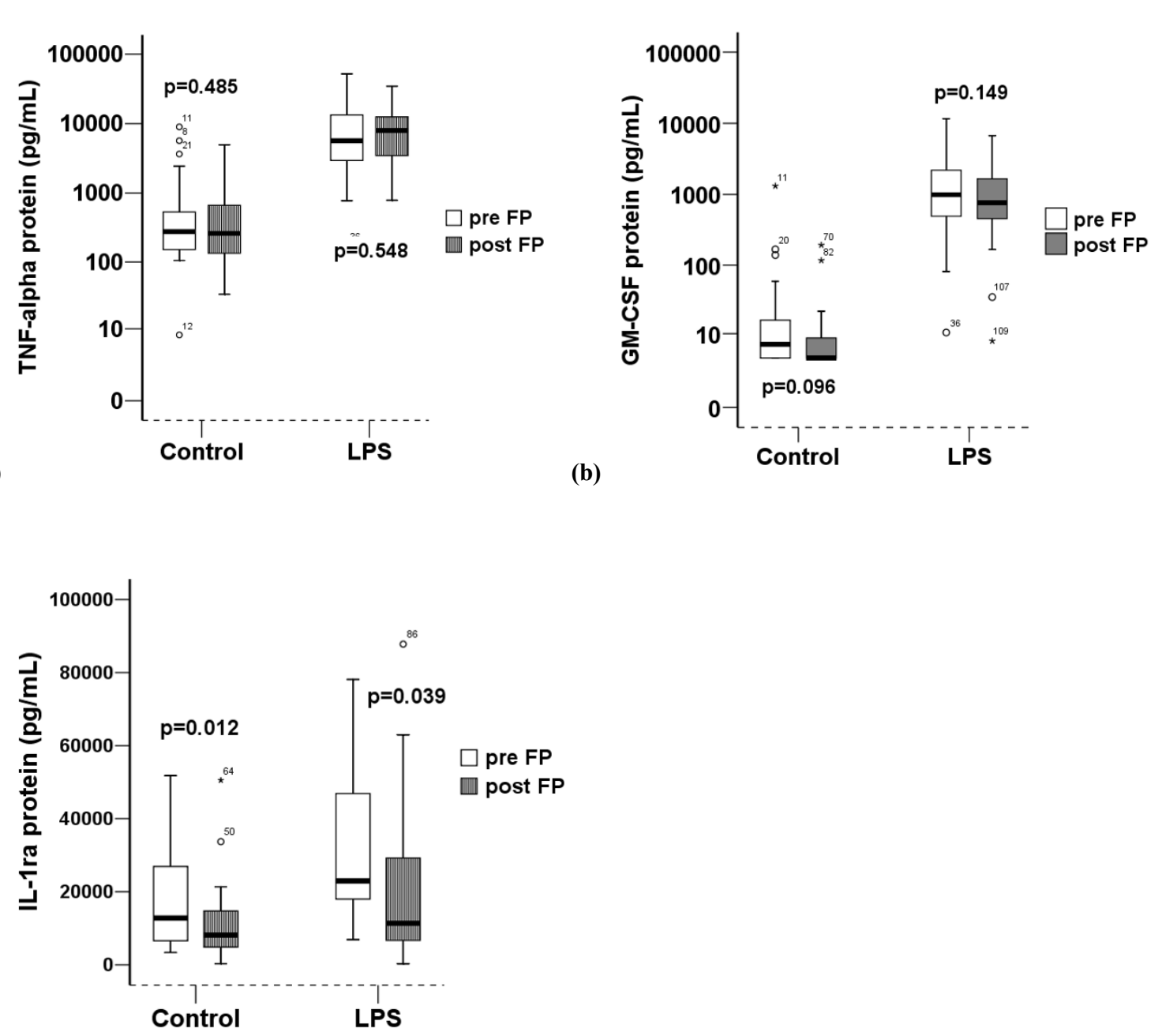

(c)

Figure 3 Comparison of cytokine protein concentrations pre and post FP $(\mathbf{n}=\mathbf{2 2}$ ). (a) TNF- $\alpha$, (b) GM-CSF, (c) IL-1 ra. LPS = Lipopolysaccharide. Control = unstimulated sample. Graphical representation is by box and whisker with medians and interquartile ranges.

study inhaled FP significantly reduced mRNA expression of the pro-inflammatory cytokines GM-CSF and TNF- $\alpha$. The change in GM-CSF protein levels after FP treatment was smaller than the estimated effect size of 1500 $\mathrm{pg} / \mathrm{mL}$. This estimate was derived from a study which had assessed the effect of inhaled budesonide $(800 \mu \mathrm{g}$ twice daily) in comparison to placebo [48], given the lack of available data quantifying the dose-dependent effects of inhaled corticosteroids on airway cytokines. A smaller effect size would be expected between two active treatment arms of different doses than between active treatment and placebo but, while this difference may be considered clinically significant, a greater number of participants in each group would have been required to show statistical significance. The effect size from two previous studies which measured alveolar macrophage TNF- $\alpha$ protein reduction post inhaled flunisolide [60] (in the order of $50 \mathrm{pg} / \mathrm{mL}$ ) differed greatly compared with post inhaled beclomethasone [66] (in the order of $140,000 \mathrm{pg} / \mathrm{mL}$ ). Therefore, although TNF- $\alpha$ is an important biological endpoint in this study, the effect of inhaled steroid treatment on TNF- $\alpha$ may depend on factors that are, as yet, undefined making the lack of significant effect of FP on TNF- $\alpha$ protein in the present study difficult to interpret. Inhaled or systemic corticosteroids suppress inflammatory cytokines in vitro including GM-CSF or TNF- $\alpha[40,48,66-73]$. Previous in vitro studies have shown that inhibition of pro-inflammatory cytokines by corticosteroids is dose-dependent $[32,33]$ and it was postulated that the in vivo effects of treatment on the same inflammatory markers would also be dose-dependent. The present study, however, found no significant difference between low and high dose inhaled FP groups in the change in quantity of constitutive and 
LPS induced cytokine mRNA and protein from alveolar macrophages.

The anti-inflammatory cytokine IL-1ra mRNA expression and IL-1ra protein was also significantly suppressed by inhaled FP in the present study. Previous studies examining the effects of ICSs on IL-1ra show conflicting results ranging from no effect $[54,74]$ to elevation of IL1 ra levels post treatment $[52,74]$. In the current study, the finding of a reduction in IL-1ra mRNA and protein after treatment with FP was unexpected considering this cytokine has anti-inflammatory properties. Epithelial expression of IL- $1 \beta$ is significantly inhibited by inhaled BDP in asthmatic subjects without any significant concurrent inhibition of IL-1ra thus favouring an antiinflammatory shift in the ratio of IL-1 / IL-1ra [54]. It is possible that the pro-inflammatory cytokine IL-1 , which was not measured in this study, may have been attenuated by FP to a greater extent than was IL-1ra, thus resulting in a lower, more anti-inflammatory ratio of IL-1 $\beta$ to IL-1ra levels.

The present study found no significant changes in the anti-inflammatory cytokine IL-10 gene expression or protein secretion resulting from treatment with FP. The small differences in IL-10 protein levels detected after FP treatment were substantially smaller than the 260 $\mathrm{pg} / \mathrm{mL}$ reported previously. The levels of IL-10 were close to the lower limit of detection in many subjects making resolution of changes impossible. Previous studies have revealed mixed effects of corticosteroids on IL-10, including no effect of in vitro dexamethasone [75], elevation after high dose inhaled budesonide [48] or inhaled triamcinolone [49] and inhibition in nonasthmatics [50].

Basement membrane thickness in asthma is reduced by corticosteroid treatment in some studies [73,76-80]. Although dose related differences in the effects of corticosteroids on bronchial mucosal BMT are apparent in some studies $[55,56]$, the current study did not demonstrate a significant reduction in BMT after FP treatment for 7 weeks. This is consistent with the findings of Boulet et al. for high dose FP [81]. Although two previous studies have shown a significant effect of short term treatment (six weeks) with medium or high dose inhaled corticosteroid on BMT [56,76], longer treatment duration (three to twelve months) is more likely to alter BMT [73,77,78,82-84].

\section{Conclusions}

An important feature of current asthma management guidelines is the use of a maintenance dose of ICS which is the minimum effective dose to achieve asthma symptom control to limit the potential for adverse effects. Current therapy guidelines also advocate alternative approaches to achieve asthma control without increasing the ICS dose.
The addition of a long-acting beta agonist, leukotriene antagonist and/or low dose theophylline represent examples of this approach. At least on a short term basis, our results suggest that in stable mild or moderate adult asthmatic patients, who are corticosteroid free for over 2 months, an FP equivalent dose of $200 \mu \mathrm{g}$ /day may be just as effective as $1000 \mu \mathrm{g} /$ day in controlling cytokine driven inflammation. Combining the different anti-asthmatic mechanisms of other therapies with the attenuation of cytokine driven inflammation by ICS might be a superior and safer approach to achieving asthma control.

It is possible that differences in inflammation may occur with longer term treatment and it would be important to conduct longitudinal studies with larger sample size to re-evaluate the dose-response relationship of a wide repertoire of inflammatory mediators, along with the probably smaller influence of dose on remodeling and fibrotic markers. Additionally, prevention of asthma exacerbations and decline in lung function would be important endpoints to assess in a long term study. It would also be useful to assess any differential dose effects of combination inhaled corticosteroid/long acting beta-agonist maintenance treatment, to firmly establish whether such low dose therapy optimally suppresses underlying inflammation and prevents long term airway remodeling and not just short term symptoms.

\section{Acknowledgements}

The authors thank Professor Guy Marks, Woolcock Institute of Medical Research, for providing statistical advice, Dr Jane Radford, Department of Pathology, University of Sydney, for cryosectioning, staining and photography of bronchial biopsies, Dr John Brannan and Dr Sandra D Anderson, Department of Respiratory Medicine, Royal Prince Alfred Hospital for the provision of mannitol and a protocol for bronchial challenge. Funding of laboratory consumables was supported by the National Health and Medical Research Council of Australia. Our gratitude extends to all of the clinical trial participants. MB was funded by a University of Sydney, Australian Postgraduate Award Scholarship.

\section{Author details}

${ }^{1}$ Woolcock Institute of Medical Research, Sydney, NSW, Australia. ${ }^{2}$ Sydney Medical School, University of Sydney, Sydney, NSW, Australia. ${ }^{3}$ Department of Respiratory Medicine, Liverpool Hospital, Sydney, NSW, Australia. ${ }^{4}$ Department of Respiratory Medicine, Royal Prince Alfred Hospital, Sydney, NSW, Australia. ${ }^{5}$ ANZAC Research Institute, Sydney, NSW, Australia. ${ }^{6}$ The Cooperative Research Centre for Asthma, Glebe, NSW, Australia. 'Department of Respiratory Medicine, Royal North Shore Hospital, Sydney, NSW, Australia.

\section{Authors' contributions}

MB contributed to study design, conducted the study, clinical tests and laboratory experiments and drafted the manuscript. BGGO helped with some experiments and provided laboratory technical advice, JKB provided laboratory technical advice, SL conceived and designed the study, GGK contributed to study design and provided clinical physiology technical advice, JLB contributed to study design and provided scientific advice. All authors were involved in discussion and interpretation of results and all authors critically revised the intellectual content of the manuscript. All authors read and approved the final manuscript.

\section{Competing interests}

Between 2006-10, Dr Gregory King has received various travel sponsorships from Boehringer Ingelheim, Pfizer, AstraZeneca and GlaxoSmithKline for 
travel and accommodation to attend international, local and interstate meetings that include Pharmaceutical Industry sponsored meetings and independent Society Scientific meetings. A proportion of Dr King's research work is conducted at the Woolcock Institute of Medical Research, which receives unrestricted grants from Boehringer Ingelheim, AstraZeneca and GlaxoSmithKline, Pharmaxis and which also has current and past consultancy agreements with Pfizer, Boehringer Ingelheim, AstraZeneca and GlaxoSmithKline. Dr King provides consultancy services related to asthma and COPD, which include sitting on advisory boards and providing talks at local and national meetings. His research group receives a proportion of the grants and monies that arise from those companies, as part of a general allocation of those funds for research purposes across all research groups of the Woolcock Institute of Medical Research. Dr King's research group is supported from competitive grants arising from local research foundations, the National Health \& Medical Research Council of Australia, Cooperative Research Centre for Asthma and Airways and The Australian Lung Foundation. The other authors declare that they have no competing interests.

Received: 29 August 2011 Accepted: 2 February 2012

Published: 2 February 2012

\section{References}

1. Adams NP, Bestall JC, Jones PW, Lasserson TJ, Griffiths B, Cates C: Inhaled fluticasone at different doses for chronic asthma in adults and children Cochrane Database Syst Rev 2005, 3: CD003534.

2. Bousquet J, Ben-Joseph R, Messonnier M, Alemao E, Gould AL: A metaanalysis of the dose-response relationship of inhaled corticosteroids in adolescents and adults with mild to moderate persistent asthma. Clin Ther 2002, 24(1):1-20.

3. Busse WW, Chervinsky P, Condemi J, Lumry WR, Petty TL, Rennard S, et al: Budesonide delivered by Turbuhaler is effective in a dose-dependent fashion when used in the treatment of adult patients with chronic asthma. J Allergy Clin Immunol 1998, 101(4 Pt 1):457-63.

4. Pedersen S, Hansen OR: Budesonide treatment of moderate and severe asthma in children: a dose-response study. J Allergy Clin Immunol 1995, 95(1 Pt 1):29-33.

5. Shapiro G, Bronsky EA, LaForce CF, Mendelson L, Pearlman D, Schwartz RH, et al: Dose-related efficacy of budesonide administered via a dry powder inhaler in the treatment of children with moderate to severe persistent asthma. J Pediatr 1998, 132(6):976-82.

6. Masoli M, Weatherall M, Holt S, Beasley R: Clinical dose-response relationship of fluticasone propionate in adults with asthma. Thorax 2004, 59(1):16-20.

7. Jones SL, Herbison P, Cowan JO, Flannery EM, Hancox RJ, McLachlan CR, et al: Exhaled NO and assessment of anti-inflammatory effects of inhaled steroid: dose-response relationship. Eur Respir J 2002, 20(3):601-8.

8. Chanez P, Karlstrom R, Godard P: High or standard initial dose of budesonide to control mild-to-moderate asthma? Eur Respir J 2001, 17(5):856-62.

9. Tukiainen $H$, Taivainen A, Majander R, Poussa T, Svahn T, Puolijoki $H$, et al: Comparison of high and low dose of the inhaled steroid, budesonide, as an initial treatment in newly detected asthma. Respir Med 2000, 94(7):678-83.

10. Szefler SJ, Martin RJ, King TS, Boushey HA, Cherniack RM, Chinchilli VM, et al: Significant variability in response to inhaled corticosteroids for persistent asthma. J Allergy Clin Immunol 2002, 109(3):410-8.

11. Holt S, Suder A, Weatherall M, Cheng S, Shirtcliffe P, Beasley R: Doseresponse relation of inhaled fluticasone propionate in adolescents and adults with asthma: meta-analysis. Bmj 2001, 323(7307):253-6.

12. Taylor DA, Jensen MW, Kanabar V, Engelstatter R, Steinijans WW, Barnes PJ, et al: A dose-dependent effect of the novel inhaled corticosteroid ciclesonide on airway responsiveness to adenosine- 5 '-monophosphate in asthmatic patients. American Journal of Respiratory \& Critical Care Medicine 1999, 160(1):237-43.

13. Gershman NH, Wong HH, Liu JT, Fahy JV: Low- and high-dose fluticasone propionate in asthma; effects during and after treatment. Eur Respir J 2000, 15(1):11-8.

14. Swystun VA, Bhagat $R$, Kalra $S$, Jennings B, Cockcroft DW: Comparison of 3 different doses of budesonide and placebo on the early asthmatic response to inhaled allergen. J Allergy Clin Immunol 1998, 102(3):363-7.
15. Jatakanon A, Kharitonov S, Lim S, Barnes PJ: Effect of differing doses of inhaled budesonide on markers of airway inflammation in patients with mild asthma. Thorax 1999, 54(2):108-14.

16. Dal Negro R, Micheletto C, Tognella S, Turco P, Rossetti A, Cantini L: Assessment of inhaled BDP-dose dependency of exhaled nitric oxide and local and serum eosinophilic markers in steroids-naive nonatopic asthmatics. Allergy 2003, 58(10):1018-22.

17. Kharitonov SA, Donnelly LE, Montuschi P, Corradi M, Collins JV, Barnes PJ: Dose-dependent onset and cessation of action of inhaled budesonide on exhaled nitric oxide and symptoms in mild asthma. Thorax 2002, 57(10):889-96.

18. Visser MJ, van der Veer E, Postma DS, Arends LR, de Vries TW, Brand PL, et al: Side-effects of fluticasone in asthmatic children: no effects after dose reduction. Eur Respir J 2004, 24(3):420-5.

19. Donnelly R, Williams KM, Baker AB, Badcock CA, Day RO, Seale JP: Effects of budesonide and fluticasone on 24-hour plasma cortisol. A doseresponse study. American Journal of Respiratory \& Critical Care Medicine 1997, 156(6):1746-51.

20. Nielsen LP, Dahl R: Therapeutic ratio of inhaled corticosteroids in adult asthma. A dose-range comparison between fluticasone propionate and budesonide, measuring their effect on bronchial hyperresponsiveness and adrenal cortex function. Am J Respir Crit Care Med 2000, 162(6):2053-7.

21. Visser MJ, Postma DS, Arends LR, de Vries TW, Duiverman EJ, Brand PL: One-year treatment with different dosing schedules of fluticasone propionate in childhood asthma. Effects on hyperresponsiveness, lung function, and height. Am J Respir Crit Care Med 2001, 164(11):2073-7.

22. Wilson AM, McFarlane LC, Lipworth BJ: Dose-response effect for adrenal suppression with repeated twice daily inhaled fluticasone propionate and triamcinolone acetonide in adult asthmatics. American Journal of Respiratory \& Critical Care Medicine 1997, 156(4 Pt 1):1274-7.

23. Wilson AM, Sims EJ, Lipworth BJ: Dose response with fluticasone propionate on adrenocortical activity and recovery of basal and stimulated responses after stopping treatment. Clinical Endocrinology 1999, 50(3):329-35

24. Fowler SJ, Orr LC, Wilson AM, Sims EJ, Lipworth BJ: Dose-response for adrenal suppression with hydrofluoroalkane formulations of fluticasone propionate and beclomethasone dipropionate. British Journal of Clinical Pharmacology 2001, 52(1):93-5.

25. Lipworth BJ: Systemic adverse effects of inhaled corticosteroid therapy: A systematic review and meta-analysis. Archives of Internal Medicine 1999, 159(9):941-55.

26. Masoli M, Holt S, Weatherall M, Beasley R: Dose-response relationship of inhaled budesonide in adult asthma: a meta-analysis. Eur Respir J 2004, 23(4):552-8

27. Nathan RA, Li JT, Finn A, Jones R, Payne JE, Wolford JP, et al: A doseranging study of fluticasone propionate administered once daily via multidose powder inhaler to patients with moderate asthma. Chest 2000, 118(2):296-302.

28. Raphael GD, Lanier RQ, Baker J, Edwards L, Rickard K, Lincourt WR: A comparison of multiple doses of fluticasone propionate and beclomethasone dipropionate in subjects with persistent asthma. $J$ Allergy Clin Immunol 1999, 103(5 Pt 1):796-803.

29. Wolfe JD, Selner JC, Mendelson LM, Hampel F Jr, Schaberg A: Effectiveness of fluticasone propionate in patients with moderate asthma: a doseranging study. Clin Ther 1996, 18(4):635-46.

30. Dahl R, Lundback B, Malo JL, Mazza JA, Nieminen MM, Saarelainen P, et a: A dose-ranging study of fluticasone propionate in adult patients with moderate asthma. International Study Group. Chest 1993, 104(5):1352-8.

31. Hofstra WB, Neijens HJ, Duiverman EJ, Kouwenberg JM, Mulder PG, Kuethe MC, et al: Dose-responses over time to inhaled fluticasone propionate treatment of exercise- and methacholine-induced bronchoconstriction in children with asthma. Pediatr Pulmonol 2000 29(6):415-23.

32. Powell N, Till SJ, Kay AB, Corrigan CJ: The topical glucocorticoids beclomethasone dipropionate and fluticasone propionate inhibit human T-cell allergen-induced production of IL-5, IL-3 and GM-CSF mRNA and protein. Clin Exp Allergy 2001, 31(1):69-76.

33. Ek A, Larsson K, Siljerud S, Palmberg L: Fluticasone and budesonide inhibit cytokine release in human lung epithelial cells and alveolar macrophages. Allergy 1999, 54(7):691-9. 
34. Joseph M, Tonnel AB, Torpier G, Capron A, Arnoux B, Benveniste J: Involvement of immunoglobulin $\mathrm{E}$ in the secretory processes of alveolar macrophages from asthmatic patients. J Clin Invest 1983, 71(2):221-30.

35. Gosset P, Tillie-Leblond I, Oudin S, Parmentier O, Wallaert B, Joseph M, et al: Production of chemokines and proinflammatory and antiinflammatory cytokines by human alveolar macrophages activated by lgE receptors. $J$ Allergy Clin Immunol 1999, 103(2 Pt 1):289-97.

36. Viksman MY, Bochner BS, Peebles RS, Schleimer RP, Liu MC: Expression of activation markers on alveolar macrophages in allergic asthmatics after endobronchial or whole-lung allergen challenge. Clin Immunol 2002 104(1):77-85.

37. Soloperto M, Mattoso VL, Fasoli A, Mattoli S: A bronchial epithelial cellderived factor in asthma that promotes eosinophil activation and survival as GM-CSF. Am J Physiol 1991, 260(6 Pt 1):L530-8.

38. Robinson DS, Hamid Q, Ying S, Tsicopoulos A, Barkans J, Bentley AM, et al Predominant TH2-like bronchoalveolar T-lymphocyte population in atopic asthma. N Engl J Med 1992, 326(5):298-304.

39. Ackerman V, Marini M, Vittori E, Bellini A, Vassali G, Mattoli S: Detection of cytokines and their cell sources in bronchial biopsy specimens from asthmatic patients. Relationship to atopic status, symptoms, and level of airway hyperresponsiveness. Chest 1994, 105(3):687-96.

40. Sousa AR, Poston RN, Lane SJ, Nakhosteen JA, Lee TH: Detection of GMCSF in asthmatic bronchial epithelium and decrease by inhaled corticosteroids. Am Rev Respir Dis 1993, 147(6 Pt 1):1557-61.

41. Woolley KL, Adelroth E, Woolley MJ, Ellis R, Jordana M, O'Byrne PM: Effects of allergen challenge on eosinophils, eosinophil cationic protein, and granulocyte-macrophage colony-stimulating factor in mild asthma. Am J Respir Crit Care Med 1995, 151(6):1915-24.

42. Yamashita N, Tashimo H, Ishida H, Kaneko F, Nakano J, Kato H, et al Attenuation of airway hyperresponsiveness in a murine asthma model by neutralization of granulocyte-macrophage colony-stimulating factor (GM-CSF). Cell Immunol 2002, 219(2):92-7.

43. Anticevich SZ, Hughes JM, Black JL, Armour CL: Induction of human airway hyperresponsiveness by tumour necrosis factor-alpha. Eur $\mathrm{J}$ Pharmacol 1995, 284(1-2):221-5

44. Thomas PS, Yates DH, Barnes PJ: Tumor necrosis factor-alpha increases airway responsiveness and sputum neutrophilia in normal human subjects. Am J Respir Crit Care Med 1995, 152(1):76-80.

45. Moore KW, de Waal Malefyt R, Coffman RL, O'Garra A: Interleukin-10 and the interleukin-10 receptor. Annu Rev Immunol 2001, 19:683-765.

46. Schandene L, Alonso-Vega C, Willems F, Gerard C, Delvaux A, Velu T, et al: B7/CD28-dependent IL-5 production by human resting $T$ cells is inhibited by IL-10. J Immunol 1994, 152(9):4368-74.

47. Takanaski S, Nonaka R, Xing Z, O'Byrne P, Dolovich J, Jordana M: Interleukin 10 inhibits lipopolysaccharide-induced survival and cytokine production by human peripheral blood eosinophils. Journal of Experimental Medicine 1994, 180(2):711-715.

48. John M, Lim S, Seybold J, Jose P, Robichaud A, O'Connor B, et al: Inhaled corticosteroids increase interleukin-10 but reduce macrophage inflammatory protein-1alpha, granulocyte-macrophage colonystimulating factor, and interferon-gamma release from alveolar macrophages in asthma. Am J Respir Crit Care Med 1998, 157(1):256-62.

49. Stelmach I, Jerzynska J, Kuna P: A randomized, double-blind trial of the effect of glucocorticoid, antileukotriene and beta-agonist treatment on IL-10 serum levels in children with asthma. Clin Exp Allergy 2002, 32(2):264-9.

50. Borish L, Aarons A, Rumbyrt J, Cvietusa P, Negri J, Wenzel S: Interleukin-10 regulation in normal subjects and patients with asthma. J Allergy Clin Immunol 1996, 97(6):1288-96.

51. Sousa A, Lane S, Nakhosteen J, Lee T, Poston R: Expression of interleukin-1 beta (IL-1beta) and interleukin-1 receptor antagonist (IL-1ra) on asthmatic bronchial epithelium. Am J Respir Crit Care Med 1996, 154(4):1061-1066.

52. Yoshida S, Hashimoto S, Nakayama T, Kobayashi T, Koizumi A, Horie T: Elevation of serum soluble tumour necrosis factor (TNF) receptor and IL1 receptor antagonist levels in bronchial asthma. Clin Exp Immunol 1996, 106(1):73-8.

53. Watson ML, Smith D, Bourne AD, Thompson RC, Westwick J: Cytokines contribute to airway dysfunction in antigen-challenged guinea pigs: inhibition of airway hyperreactivity, pulmonary eosinophil accumulation, and tumor necrosis factor generation by pretreatment with an interleukin-1 receptor antagonist. Am J Respir Cell Mol Biol 1993, 8(4):365-9.

54. Sousa AR, Trigg CJ, Lane SJ, Hawksworth R, Nakhosteen JA, Poston RN, et al: Effect of inhaled glucocorticoids on IL-1 beta and IL-1 receptor antagonist (IL-1 ra) expression in asthmatic bronchial epithelium. Thorax 1997, 52(5):407-10.

55. Sont JK, Willems LN, Bel EH, van Krieken JH, Vandenbroucke JP, Sterk PJ: Clinical control and histopathologic outcome of asthma when using airway hyperresponsiveness as an additional guide to long-term treatment. The AMPUL Study Group. Am J Respir Crit Care Med 1999, 159(4 Pt 1):1043-51.

56. Chetta A, Zanini A, Foresi A, Del Donno M, Castagnaro A, D'lppolito R, et al: Vascular component of airway remodeling in asthma is reduced by high dose of fluticasone. Am J Respir Crit Care Med 2003, 167(5):751-7.

57. Brannan JD, Koskela H, Anderson SD, Chan HK: Budesonide reduces sensitivity and reactivity to inhaled mannitol in asthmatic subjects. Respirology 2002, 7(1):37-44.

58. Anderson SD, Brannan J, Spring J, Spalding N, Rodwell LT, Chan K, et al: A new method for bronchial-provocation testing in asthmatic subjects using a dry powder of mannitol. Am J Respir Crit Care Med 1997, 156(3 Pt 1):758-65.

59. Juniper EF, O'Byrne PM, Guyatt GH, Ferrie PJ, King DR: Development and validation of a questionnaire to measure asthma control. Eur Respir $J$ 1999, 14(4):902-7.

60. Bewig B, Barth J: Inhibitory effects of inhaled flunisolide on inflammatory functions of alveolar macrophages. Eur J Clin Pharmacol 1993, 44(6):541-4.

61. Lipworth BJ, Sims EJ, Das SK, Buck H, Paterson M: Dose-response comparison of budesonide dry powder inhalers using adenosine monophosphate bronchial challenge. Ann Allergy Asthma Immunol 2005, 94(6):675-81

62. Viksman MY, Liu MC, Bickel CA, Schleimer RP, Bochner BS: Phenotypic analysis of alveolar macrophages and monocytes in allergic airway inflammation. I: Evidence for activation of alveolar macrophages, but not peripheral blood monocytes, in subjects with allergic rhinitis and asthma. Am J Respir Crit Care Med 1997, 155(3):858-63.

63. Alexis NE, Soukup J, Nierkens S, Becker S: Association between airway hyperreactivity and bronchial macrophage dysfunction in individuals with mild asthma. Am J Physiol Lung Cell Mol Physiol 2001, 280(2):L369-75.

64. Huynh ML, Malcolm KC, Kotaru C, Tilstra JA, Westcott JY, Fadok VA, et al: Defective apoptotic cell phagocytosis attenuates prostaglandin E2 and 15-hydroxyeicosatetraenoic acid in severe asthma alveolar macrophages. Am J Respir Crit Care Med 2005, 172(8):972-9.

65. Nomura H, Sato E, Koyama S, Haniuda M, Kubo K, Nagai S, et al: Histamine stimulates alveolar macrophages to release neutrophil and monocyte chemotactic activity. J Lab Clin Med 2001, 138(4):226-35.

66. Marshall BG, Wangoo A, Harrison LI, Young DB, Shaw RJ: Tumour necrosis factor-alpha production in human alveolar macrophages: modulation by inhaled corticosteroid. Eur Respir J 2000, 15(4):764-70.

67. Cotter TP, Hood PP, Costello JF, Sampson AP: Exposure to systemic prednisolone for 4 hours reduces ex vivo synthesis of GM-CSF by bronchoalveolar lavage cells and blood mononuclear cells of mild allergic asthmatics. Clin Exp Allergy 1999, 29(12):1655-62.

68. Linden M, Brattsand R: Effects of a corticosteroid, budesonide, on alveolar macrophage and blood monocyte secretion of cytokines: differential sensitivity of GM-CSF, IL-1 beta, and IL-6. Pulm Pharmacol 1994, 7(1):43-7.

69. Vecchiarelli A, Siracusa A, Cenci E, Puliti M, Abbritti G: Effect of corticosteroid treatment on interleukin-1 and tumour necrosis factor secretion by monocytes from subjects with asthma. Clin Exp Allergy 1992, 22(3):365-70.

70. Nakamura Y, Ozaki T, Kamei T, Kawaji K, Banno K, Miki S, et al: Increased granulocyte/macrophage colony-stimulating factor production by mononuclear cells from peripheral blood of patients with bronchial asthma. Am Rev Respir Dis 1993, 147(1):87-91.

71. Lai CK, Ho SS, Chan CH, Leung R, Lai KN: Gene expression of interleukin-3 and granulocyte macrophage colony-stimulating factor in circulating CD4+ T cells in acute severe asthma. Clin Exp Allergy 1996, 26(2):138-46.

72. Wang JH, Trigg CJ, Devalia JL, Jordan S, Davies RJ: Effect of inhaled beclomethasone dipropionate on expression of proinflammatory cytokines and activated eosinophils in the bronchial epithelium of patients with mild asthma. J Allergy Clin Immunol 1994, 94(6 Pt 1):1025-34. 
73. Trigg CJ, Manolitsas ND, Wang J, Calderon MA, McAulay A, Jordan SE, et al: Placebo-controlled immunopathologic study of four months of inhaled corticosteroids in asthma. Am J Respir Crit Care Med 1994, 150(1):17-22.

74. Amrol DJ, Hagaman DD, Sheller JR, Murray JJ: Soluble CD23 and interleukin-1 receptor antagonist in human asthmatics following antigen challenge. J Asthma 2005, 42(1):73-6.

75. Colavita AM, Hastie AT, Musani Al, Pascual RM, Reinach AJ, Lustine HT, et al: Kinetics of IL-10 production after segmental antigen challenge of atopic asthmatic subjects. J Allergy Clin Immunol 2000, 106(5):880-6.

76. Olivieri D, Chetta A, Del Donno M, Bertorelli G, Casalini A, Pesci A, et al: Effect of short-term treatment with low-dose inhaled fluticasone propionate on airway inflammation and remodeling in mild asthma: a placebo-controlled study. Am J Respir Crit Care Med 1997, 155(6):1864-71.

77. Capraz F, Kunter E, Cermik H, Ilvan A, Pocan S: The effect of inhaled budesonide and formoterol on bronchial remodeling and HRCT features in young asthmatics. Lung 2007, 185(2):89-96.

78. Hoshino M, Nakamura Y, Sim JJ, Yamashiro Y, Uchida K, Hosaka K, et al: Inhaled corticosteroid reduced lamina reticularis of the basement membrane by modulation of insulin-like growth factor (IGF)-I expression in bronchial asthma. Clin Exp Allergy 1998, 28(5):568-77.

79. Hoshino M, Takahashi M, Takai Y, Sim J: Inhaled corticosteroids decrease subepithelial collagen deposition by modulation of the balance between matrix metalloproteinase- 9 and tissue inhibitor of metalloproteinase-1 expression in asthma. J Allergy Clin Immunol 1999, 104(2 Pt 1):356-63.

80. Laitinen A, Altraja A, Kampe M, Linden M, Virtanen I, Laitinen LA: Tenascin is increased in airway basement membrane of asthmatics and decreased by an inhaled steroid. Am J Respir Crit Care Med 1997, 156(3 Pt 1):951-8.

81. Boulet LP, Turcotte H, Laviolette M, Naud F, Bernier MC, Martel S, et al Airway hyperresponsiveness, inflammation, and subepithelial collagen deposition in recently diagnosed versus long-standing mild asthma. Influence of inhaled corticosteroids. Am J Respir Crit Care Med 2000, 162(4 Pt 1):1308-13.

82. Hoshino M, Nakamura Y, Sim JJ, Tomioka H: A comparative study of the effects of ketotifen, disodium cromoglycate, and beclomethasone dipropionate on bronchial mucosa and asthma symptoms in patients with atopic asthma. Respir Med 1998, 92(7):942-50.

83. Ward C, Pais M, Bish R, Reid D, Feltis B, Johns D, et al: Airway inflammation, basement membrane thickening and bronchial hyperresponsiveness in asthma. Thorax 2002, 57(4):309-16.

84. Ward C, Reid DW, Orsida BE, Feltis B, Ryan VA, Johns DP, et al: Interrelationships between airway inflammation, reticular basement membrane thickening and bronchial hyper-reactivity to methacholine in asthma; a systematic bronchoalveolar lavage and airway biopsy analysis. Clin Exp Allergy 2005, 35(12):1565-71.

doi:10.1186/1465-9921-13-11

Cite this article as: Baraket et al:: Is low dose inhaled corticosteroid therapy as effective for inflammation and remodeling in asthma? A randomized, parallel group study. Respiratory Research 2012 13:11.

\section{Submit your next manuscript to BioMed Central and take full advantage of:}

- Convenient online submission

- Thorough peer review

- No space constraints or color figure charges

- Immediate publication on acceptance

- Inclusion in PubMed, CAS, Scopus and Google Scholar

- Research which is freely available for redistribution

Submit your manuscript at www.biomedcentral.com/submit
Biomed Central 